\title{
EVALUATION OF FEEDING INDICES TO ANALYSE THE FOOD PREFERENCE AND FEEDING RATE OF MACROBRACHIUM ASSAMENSE PENINSULARE (TIWARI, 1958) FROM RAWASAN STREAM OF GARHWAL, CENTRAL HIMALAYA, INDIA
}

\author{
Koshal Kumar $^{1 *}$, Anita Rawat Rana ${ }^{2}$ and Chandra Bhanu Kotnala ${ }^{1}$ \\ ${ }^{I}$ Department of Zoology, HNB Garhwal University (A Central University), BGR Campus Pauri, Garhwal \\ - 246001, Uttarakhand, India. \\ ${ }^{2}$ Department of Zoology, Government PG College (Autonomous), Rishikesh - 249202, Dehradun, \\ Uttarakhand, India.
}

*Corresponding Author Email id: koshalbagelu@gmail.com

Received: 02.10.2020; Revised: 20.10.2020; Accepted: 13.11.2020

@Society for Himalayan Action Research and Development

\begin{abstract}
In this paper the feeding index (FI), Gastro somatic index (GaSI) and Food Prevalence Index (FPI) of freshwater prawn Macrobrachium assamense peninsulare were evaluated to assess the quantity and quality of food preferred by it in the Rawasan stream. A total of 401 prawns were collected during a span of two years from five selected sites in the Rawasan stream of Garhwal in Central Himalaya, India from August 2013 to July 2015. Collected prawns were in the size range of 20-75 $\mathrm{mm}$ in males and 24-65 $\mathrm{mm}$ in females in total length. The stomach contents of 10 collected specimens were examined monthly and observed that $35 \%$ of the stomach was full or semifull and $15 \%$ stomach were empty. The highest Gastro somatic value was obtained $2.95 \pm 0.80$ during June in the male and 3.25 \pm 0.44 during May in the female. After that, it gradually decreased in both the sexes and is repeated in cyclic patterns each year. More or less a similar trend was reported in the feeding index value during the study which indicates a significant relationship between feeding intensity and Gastro somatic index. The highest Food Prevalence Index (FPI) was seen as fragments of animal matter in both sexes, which was (88.48) in male and (58.26) in female prawns and the lowest FPI value was sand and debris (7.9 and 5.7) in male and female prawn respectively. The main food items were the fragment of plants as well as animals, diatoms, algae, and sand. Overall, the results show that this prawn is selectively abstemious.
\end{abstract}

Keywords: Feeding index, Gastro somatic index, Food Prevalence Index, Freshwater prawn

\section{Introduction}

Food is considered to be one of the essential requirements of any living organism. Like other living organisms prawn also depends on the energy received from its possible food to perform several physiological activities comprising growth, maintenance, reproduction and metabolism. Feeding is one of the main concerns of daily living in all aquatic animals, in which they devote a large portion of energy searching for food. The knowledge of the natural diet of a species, therefore, is not only an important component of its biology but it also permits to judge the interaction of the animal with other organisms and the environment in which they live. The feed is the most essential input for the culture of any aquatic species and protein is pivotal in shellfish feed. In formulating a diet for fish and shellfish, low-cost feed ingredients are generally used to compose appropriate cost-effective feed. Among decapod crustaceans, freshwater prawn 
inhabits the benthic region of the water body and feed on microscopic food. Members of the genus Macrobrachium are adapted themselves to a wide range of food of both plant and animal origin and are reported as omnivores in their feeding habits (Sharma and Subba, 2005; Jimoh et al. 2011). With the help of chelates of the thoracic legs, food is grabbed and taken into the mouth where further cutting through maxillipeds and grinding into minute particles through mandibles occur. The gastric mills' ossicle and mouthparts of crustaceans crush the food so minutely that it becomes very difficult to identify the contents of food. The foregut content analyses are thus used to collect information on the natural diet of these crustaceans (Lima et al. 2014). The food requirements of the macro crustacean are also influenced by other factors, the efficiency of food utilization and assimilation. The selection of an experimental diet has frequently been assessed in terms of food conservation ratio (Froster, 1976; Reddy and Shakuntala, 1986). The study of food and feeding assumes immense significance in biological investigations. However, relevant data on the feeding requirement of minor freshwater prawn is limited. This paper is expected to develop the data on food and feeding habits of Macrobrachium assamense peninsulare (Figure 1) from Rawasan stream in Uttarakhand. Extensive studies on the food and feeding of Palaemonid prawn of the world have been carried out by several workers (Marte,1980; Jayachandra, and Joseph; 1989, Murthy and Rajagopal, 1990; Jimoh et al. 2011; Baskar et al. 2013; Lima et al. 2014; Koshal Kumar et al. 2016).

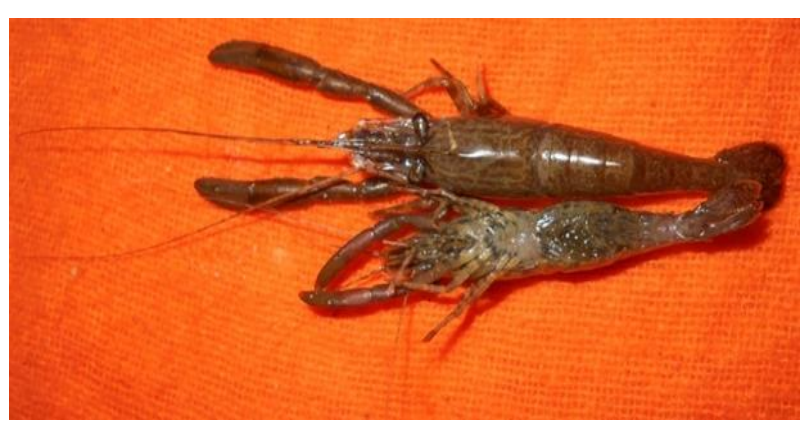

Figure 1: Freshwater prawn, (Macrobrachium assamense peninsulare)

\section{Materials and Methods}

The study was carried out in a tributary of River Ganga i.e., Rawasan stream in Pauri district of Uttarakhand, India, which is bounded by $29^{\circ} 55^{\prime} 33.82^{\prime \prime} \mathrm{N}$ and $78^{\circ} 26^{\prime} 42.41^{\prime \prime} \mathrm{E}$ having an elevation of 2,664.04 feet and an eye altitude 13,320.21 feet. The selection of sites was purposefully based on the availability of specimens, ecological zonation, and variation in latitude. A total of 401 samples were collected randomly during an interval of two years (August 2013 to July 2015). For quantities and qualitative gut content analyses randomly 10 males and 10 females were preserved in $70 \%$ alcohol on the spot every month (Williams, 1981). The prawns were collected in the early hour of the day in consecutive $2^{\text {nd }}$ week of every month. In the laboratory before proceeding with microscopic examination of food contents, the total weight of the individual intact prawn and gastric mills were recorded separately. In each specimen, the carapace was opened from the dorsal side of the body and the gut was removed carefully (Figure. 2). A visual examination of the fullness of the gut was also made immediately after its removal (Devi et al. 2013). A quick microscopic analysis of food contents was done and was never overdue for more than 4 days after capturing the animal. Various food items were examined using an inverted microscope (10-40X) and identified to the lowest possible taxonomical level with the help of several keys (Ward and Whipple, 1959; Needham and Needham, 1962; APHA 2012) The contents were identified using Magnus Micro Image Processing System (MIPS).

\section{Two feeding indices were studied as follows}

Feeding index (FI) and Gastro somatic index (GaSI) of the stomach contents of freshwater prawn Macrobrachium assamense peninsulare for each sex.

Feeding rate: The feeding rate was calculated in term of Gastro-Somatic index (GaSI) and feeding index $(\mathrm{FI})$ as under 
Gastro-Somatic index $=\frac{\text { weight of gastric mill contents }}{\text { weight of intact prawn }} \times 100$
Feeding index $=\frac{\text { weight of gastric mill contents }}{\text { weight of gastric mill (unopened) }} \times 100$

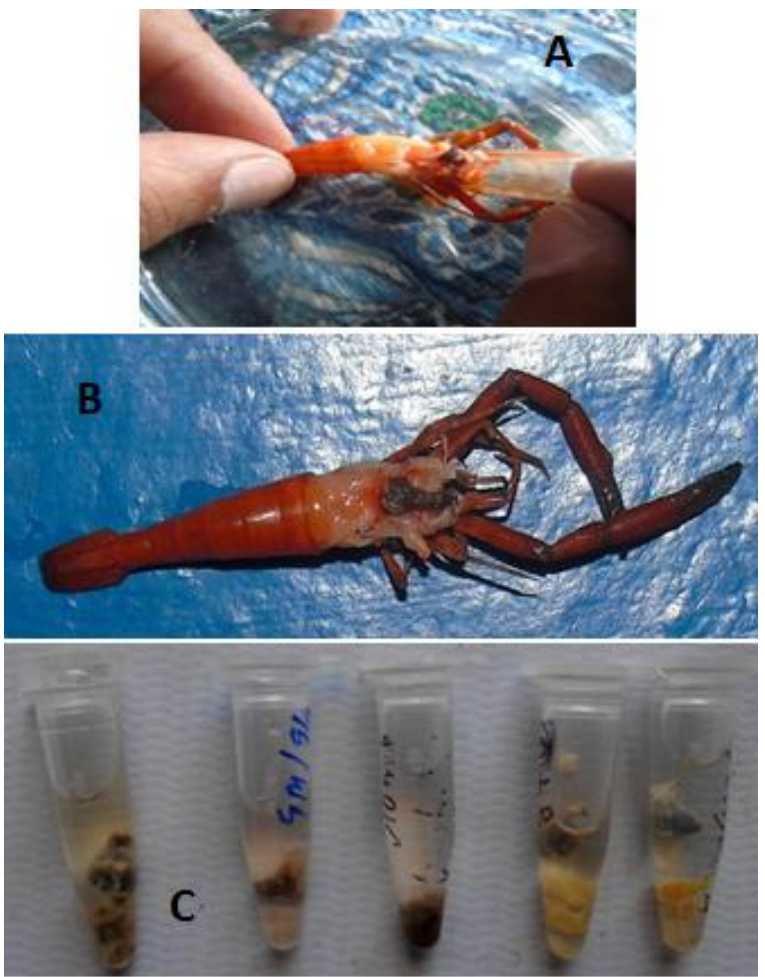

Figure 2: Gut of prawn (A) Opened carapace (B) Gut showing through cephalothorax region (C) Collection of guts in alcohol

The weight of the gastric mill contents was determined by washing out the gastric mills into a pre-weighed Petri-dish by $5 \mathrm{ml}$ of pre-weighed distilled water, using an automatic fluid dispenser. The gastric mill content weight was calculated by deducting the known weight from the final weight of the dish. Also, the diet using a Food Prevalence Index defined by Euzen, 1987; who called it "Food Preference Index" was calculated as:

$$
\mathrm{FP}_{\mathrm{j}}=\frac{N S_{j} \times 100}{N s}
$$

Where:

$\mathrm{NSj}=$ total number of individual prey of species $j$ in all samples (stomach and intestine)
Ns $=$ Total number of samples containing food.

If $\mathrm{FPj}<10$ then species $j$ is considered to be negligible in the diet. For FPj between 10 and 50, species $j$ is considered a minor prey species, and if $\mathrm{FPj}>50$ then species $j$ is the main diet item.

\section{Results}

Collected specimens of freshwater prawn (Macrobrachium assamense peninsulare) from the selected sampling sites were analyzed for feeding study by performing different indices. The animal size was in the range of $20-75 \mathrm{~mm}$ in total length, while the total weight ranged between 0.16-5.8 g in male and $0.23-2.86 \mathrm{~g}$ in female individuals. It was indicated that prawn was an omnivorous species and exhibits feeding activity in the day time in comparison to the other species. Different indices were studied and the result was as follows. All statistical analyses were performed by using Microsoft Excel 2010 and a student T-test was used to test the significance of the Gastro somatic and feeding indices.

Monthly variation in Gastro-Somatic index (GaSI): Variation in gastro-somatic index value (Means \pm SE) was recorded for both the sexes of Macrobrachium assamense peninsulare were and in Table 1. Gastro-Somatic indices showed variation in different maturity stages which was noticeable high i.e. $2.95 \pm 0.80$ during June in male and 3.25 \pm 0.44 during May in female and lowest $1.05 \pm 0.11 \& 1.30 \pm 0.07$ in males and females as shown in Table 1. This downfall in value is a cyclic process in both the sex due to annual variation in feeding. Fig 3 reveals that the highest peak was in the middle of the years and downfall linearly indicates that these prawns usually feed based on food availability of food which is directly proportional to the food items available in the stream. 
Table 1: Monthly Mean \pm SE value of Gastro-Somatic index (GaSI) of Macrobrachium assamense peninsulare

\begin{tabular}{lllll}
\hline \multirow{2}{*}{ Months } & \multicolumn{2}{l}{ Gastro-Somatic index (GaSI) } & Remarks \\
\cline { 2 - 5 } & Male & Remarks & Female & Decrease \\
\hline August & $2.18 \pm 0.21$ & Decrease & $2.46 \pm 0.02$ & Decrease \\
September & $1.80 \pm 0.043$ & Decrease & $2.33 \pm 0.12$ & Decrease \\
October & $1.58 \pm 0.21$ & Decrease & $1.81 \pm 0.02$ & Decrease \\
November & $1.42 \pm 0.08$ & Decrease & $1.73 \pm 0.02$ & Low \\
December & $1.24 \pm 0.02$ & Decrease & $\mathbf{1 . 3 0} \pm \mathbf{0 . 0 7}$ & Increase \\
January & $\mathbf{1 . 0 5} \pm \mathbf{0 . 1 1}$ & Low & $1.54 \pm 0.05$ & Increase \\
February & $1.33 \pm 0.13$ & Increase & $1.70 \pm 0.15$ & Increase \\
March & $2.47 \pm 0.76$ & Increase & $2.15 \pm 0.15$ & Increase \\
April & $2.48 \pm 0.17$ & Increase & $2.80 \pm 0.43$ & High peak \\
May & $2.58 \pm 0.36$ & Increase & $\mathbf{3 . 2 5} \pm \mathbf{0 . 4 4}$ & Downfall \\
June & $\mathbf{2 . 9 5} \pm \mathbf{0 . 8 0}$ & High peak & $2.58 \pm 0.66$ & Decrease \\
July & $2.37 \pm 0.72$ & Downfall & $2.54 \pm 0.34$ & \\
\hline
\end{tabular}

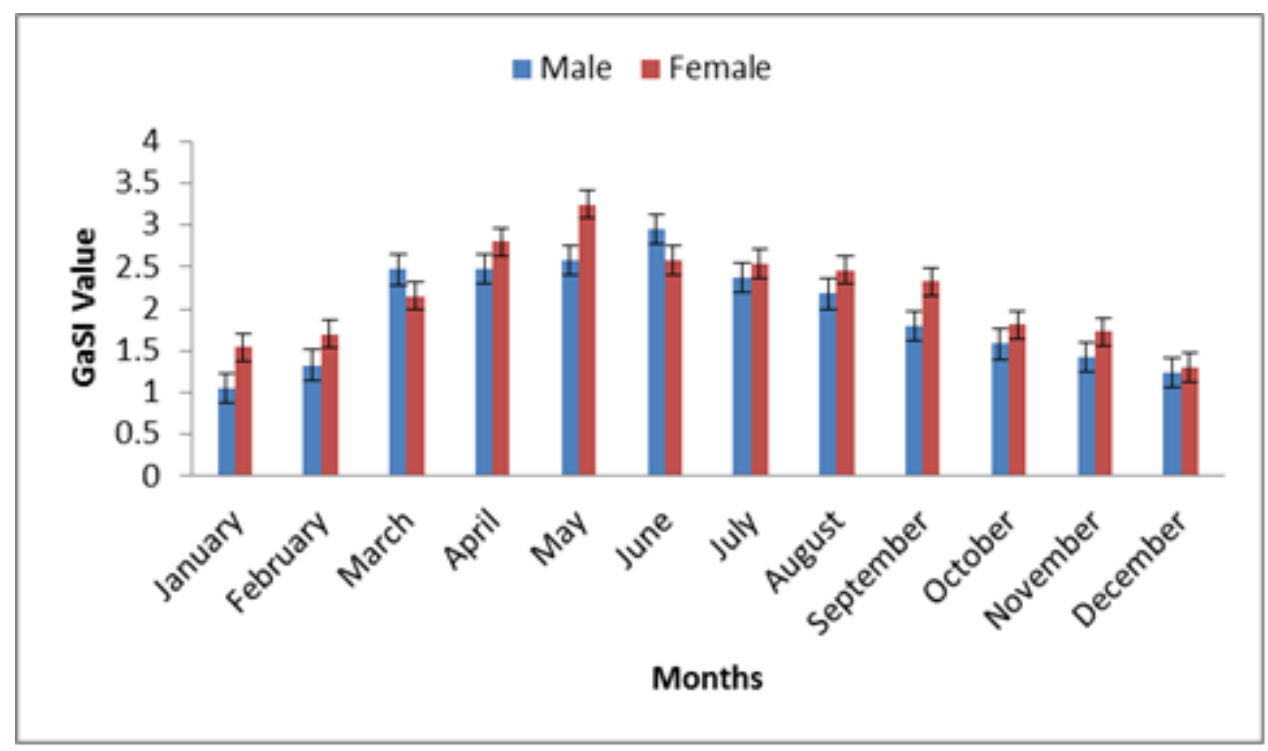

Figure 3: Monthly Variation in Gastro-Somatic index (GaSI) value of Macrobrachium assamense peninsulare

(a) Monthly variation in feeding Index (FI): Variation in feeding index value (Mean \pm SE) is depicted in Table 2 . The feeding intensity varied from highest (41.05 \pm 9.22$)$ during June and lowest (24.32 \pm 2.88$)$ during December in male and a similar trend was observed in female, ranging the highest $(38.15 \pm 4.36)$ during June and the lowest $(26.13 \pm 3.11)$ during December months. This trend was more or less similar to the GaSI index indicating the relationship between feeding intensity and Gastro somatic index. From figure 4 it has been clear that the feeding index of the animal is moderate throughout the years and the highest peak was $i$ the monsoon months, which is directly related to the abundant availability of food in the natural habitat of the prawn. 
Table 2: Monthly Mean values (Mean \pm SE) of feeding index (FI) of Macrobrachium assamense peninsulare

\begin{tabular}{llll}
\hline \multirow{2}{*}{ Months } & \multicolumn{2}{l}{ Feeding Index $(\mathbf{F I})$} & Remarks \\
\cline { 2 - 3 } Male & Female & Decrease \\
\hline August & $28.55 \pm 3.17$ & $35.41 \pm 7.88$ & Decrease \\
September & $26.45 \pm 2.21$ & $29.22 \pm 4.14$ & Decrease \\
October & $25.10 \pm 1.20$ & $28.16 \pm 5.11$ & Decrease \\
November & $24.09 \pm 1.99$ & $27.09 \pm 2.83$ & Low \\
December & $\mathbf{2 4 . 3 2} \pm \mathbf{2 . 8 8}$ & $\mathbf{2 6 . 1 3} \pm \mathbf{3 . 1 1}$ & Slow Increase \\
January & $26.46 \pm 5.62$ & $26.61 \pm 4.56$ & Increase \\
February & $32.04 \pm 2.31$ & $33.16 \pm 4.76$ & Increase \\
March & $36.32 \pm 5.11$ & $34.16 \pm 3.99$ & Increase \\
April & $34.06 \pm 4.03$ & $35.17 \pm 7.28$ & Increase \\
May & $38.21 \pm 5.78$ & $37.01 \pm 3.88$ & High \\
June & $\mathbf{4 1 . 0 5} \pm \mathbf{9 . 2 2}$ & $\mathbf{3 8 . 1 5} \pm \mathbf{4 . 3 6}$ & Downfall \\
July & $35.14 \pm 2.78$ & $36.01 \pm 3.27$ & \\
\hline
\end{tabular}

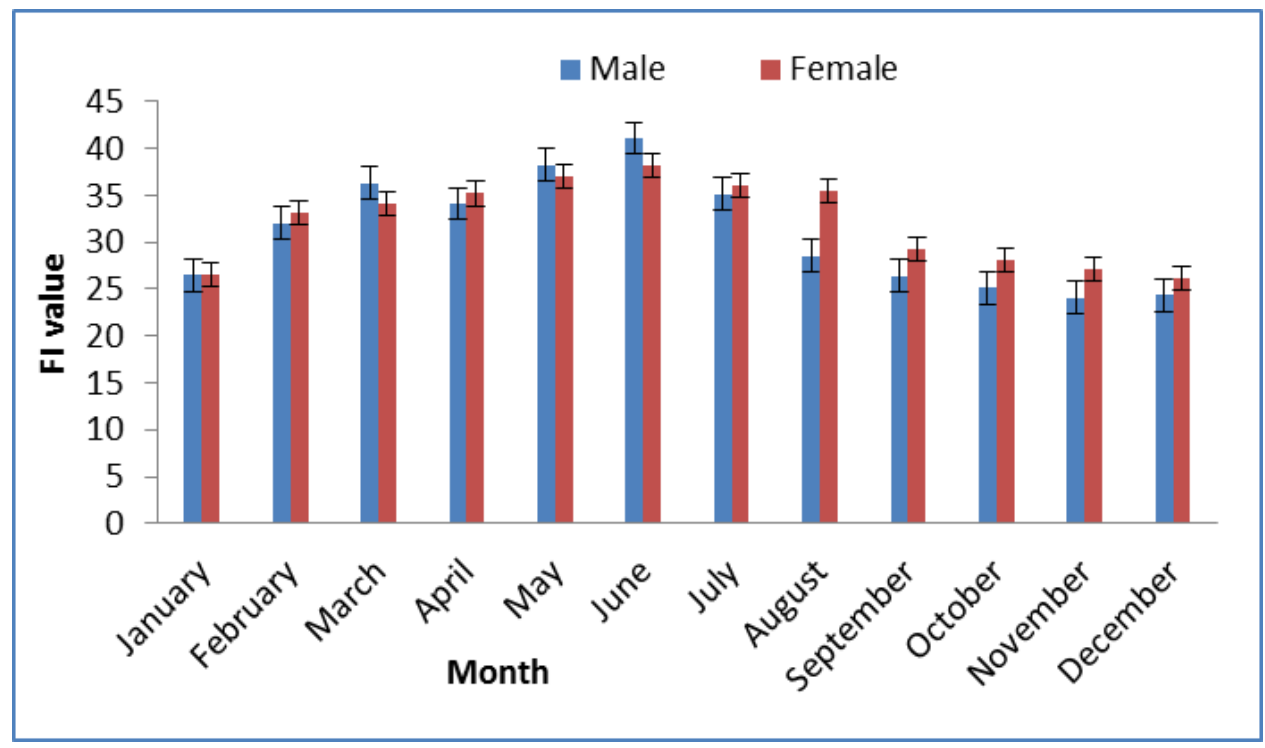

Figure 4 Monthly Variation in Feeding index (FI) value of Macrobrachium assamense peninsulare

c) Variation in Food Prevalence Index: Highest FPI value was recorded 88.48 in males and 58.26 in females, which was the fragments of animal matter (Table. 3), except for the amorphous mass and lowest diet group, was sands which are an accidental food of prawn. It has been clear from the data obtained that FPI value shows the variation in food items observed from the gut of different size groups of animals. From fig. 5, it is clear that in the case of male prawn higher bulk of food items observed was amorphous mass due to the powerful appendage of the prawn use to charm the food before reach the stomach and second was the fragment of animals matter, show omnivorous nature of animals. A similar observation was seen in female prawns in all size groups (fig. 6), but in the case of quantity-wise, fewer food items were observed as compared to the male individual of the same size and group. 
Table 3: Food Prevalence Index of Macrobrachium assamense peninsulare

\begin{tabular}{|c|c|c|c|c|c|c|}
\hline \multirow[b]{2}{*}{ Food Items } & \multicolumn{6}{|c|}{ Male prawn } \\
\hline & $\begin{array}{l}\text { Size } \\
(\mathbf{2 0 - 3 0} \\
\mathbf{m m}) \\
\mathrm{N}=9\end{array}$ & $\begin{array}{l}\text { Size } \\
(30-40 \\
\text { mm) } \\
\mathrm{N}=14\end{array}$ & $\begin{array}{l}\text { Size } \\
(40-50 \\
\text { mm) } \\
\mathrm{N}=18\end{array}$ & $\begin{array}{l}\text { Size } \\
(50-60 \\
\text { mm) } \\
N=11\end{array}$ & $\begin{array}{l}\text { Size } \\
(60-70 \\
\text { mm) } \\
\mathrm{N}=4\end{array}$ & $\begin{array}{l}\text { Total } \\
\text { prawn } \\
\mathrm{N}=56\end{array}$ \\
\hline Fragments of Aquatic plants & 0.477 & 1.302 & 1.98 & 1.21 & 0.4 & 26.656 \\
\hline $\begin{array}{l}\text { Fragments of Aquatic } \\
\text { Animals }\end{array}$ & 2.07 & 4.48 & 6.12 & 3.74 & 1.28 & 88.48 \\
\hline Algae & 1.224 & 1.2292 & 2.034 & 1.243 & 0.628 & 30.016 \\
\hline Diatoms & 0.657 & 0.644 & 0.54 & 0.33 & 0.28 & 14.504 \\
\hline Unidentified organisms & 0.558 & 0.686 & 0.594 & 0.363 & 0.072 & 11.2 \\
\hline Amorphous mass & 3.888 & 5.306 & 6.336 & 3.872 & 1.304 & 102.76 \\
\hline \multirow[t]{3}{*}{ Sand Grains } & 0.117 & 0.42 & 0.504 & 0.308 & 0.06 & 7.952 \\
\hline & \multicolumn{6}{|c|}{ Female Prawn } \\
\hline & $\begin{array}{l}\text { Size } \\
(\mathbf{2 0 - 3 0} \\
\mathbf{m m}) \\
\mathrm{N}=13\end{array}$ & $\begin{array}{l}\text { Size } \\
(30-40 \\
\text { mm) } \\
N=16\end{array}$ & $\begin{array}{l}\text { Size } \\
(40-50 \\
\text { mm) } \\
N=14\end{array}$ & $\begin{array}{l}\text { Size } \\
(50-60 \\
\text { mm) } \\
\text { N=17 }\end{array}$ & $\begin{array}{l}\text { Size } \\
(60-70 \\
\mathbf{m m}) \\
0\end{array}$ & $\begin{array}{l}\text { Total } \\
\text { prawn } \\
N=60\end{array}$ \\
\hline Fragments of Aquatic plants & 0.858 & 1.376 & 1.4 & 1.87 & 0 & 21.72 \\
\hline $\begin{array}{l}\text { Fragments of Aquatic } \\
\text { Animals }\end{array}$ & 2.522 & 3.424 & 3.234 & 5.644 & 0 & 58.26 \\
\hline Algae & 2.47 & 2.4 & 1.68 & 1.632 & 0 & 33.36 \\
\hline Diatoms & 1.079 & 1.44 & 1.05 & 1.156 & 0 & 18.96 \\
\hline Unidentified organisms & 0.5538 & 0.5168 & 0.3808 & 0.4964 & 0 & 7.878 \\
\hline Amorphous mass & 5.33 & 6.4 & 5.88 & 5.95 & 0 & 94.8 \\
\hline Sand Grains & 0.299 & 0.544 & 0.28 & 0.306 & 0 & 5.7 \\
\hline
\end{tabular}

\section{Discussion}

Variation in feeding intensity of Macrobrachium assamense peninsulare can further be confirmed by noticing the variation in GaSI value in mature females as compared to the immature female during the two year study period. A decline in feeding intensity has been reported in M. eqdidens (Murthy and Rajagopal, 1990) female with the advancement of maturity and also during molting. A similar pattern of variation has been noticed in the different maturity stages of Macrobrachium assamense peninsulare females after study the various models of indices related to feeding. A higher percentage of the empty stomach in females was recorded more as compared to the male individual due to the reduced feeding as a result of enlargement of the gonads before the spawning and occupies the significant portion of the cephalothorax (Koshal Kumar et al. 2016). GaSI of Penaeus monodon was reported by Marte, 1980 which revealed that the feeding intensity remained high during winter months and got reduced during the summer months in contradiction to the present study. 


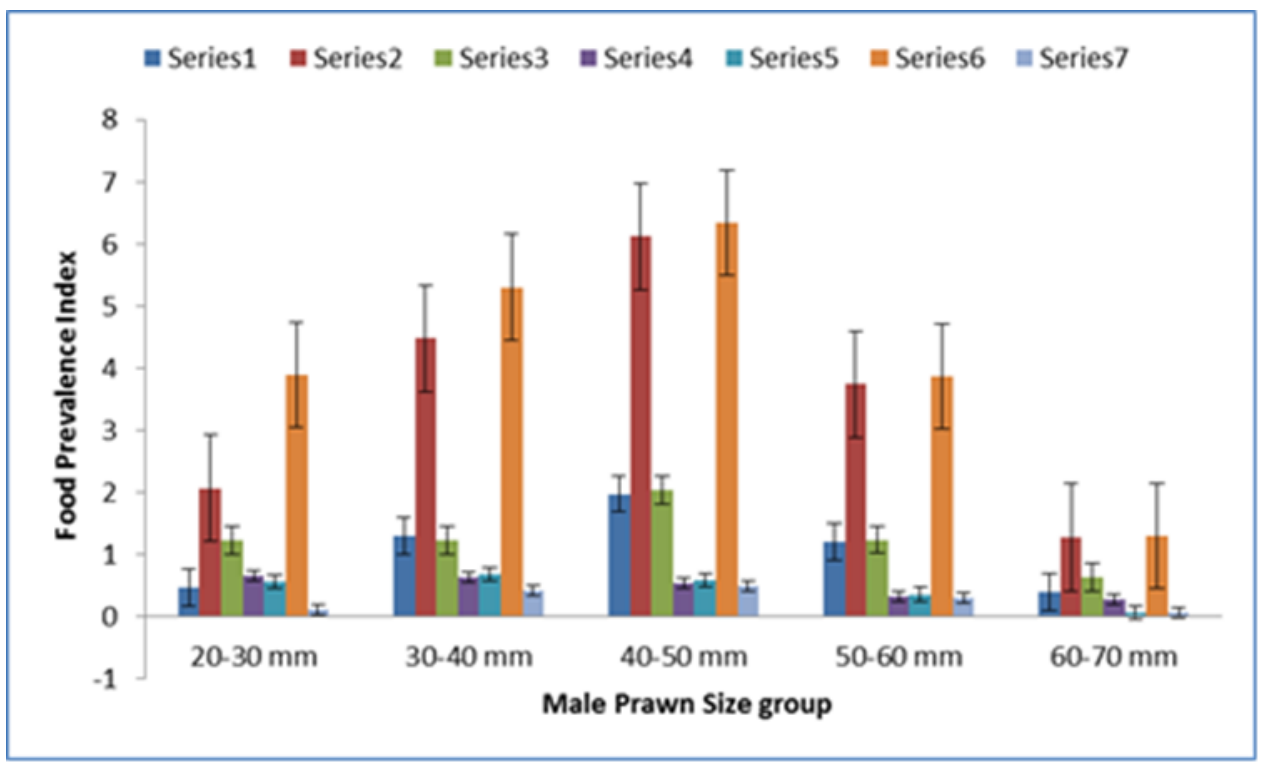

Figure 5: Food Prevalence Index showing variation in different groups in male $M$. assamense peninsulare

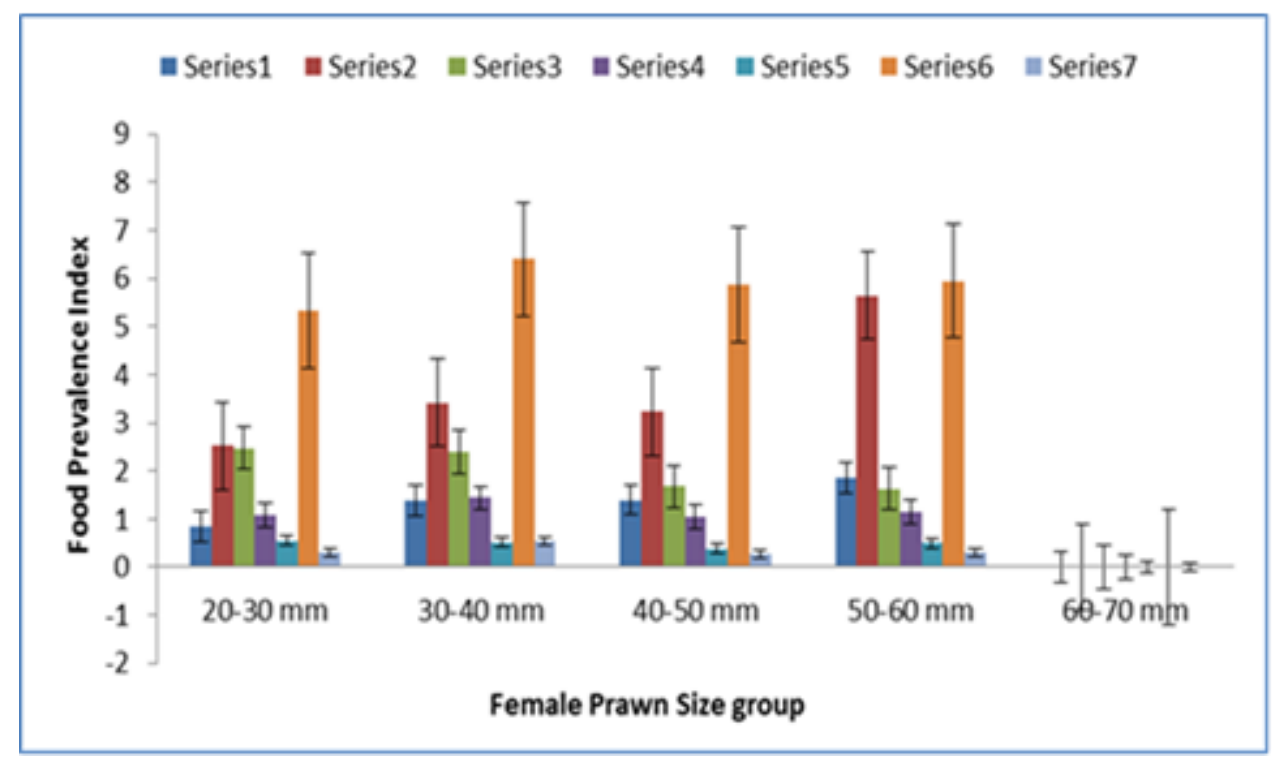

Figure 6: Food Prevalence Index showing variation in different groups in female $M$. assamense peninsulare

[Note: Series 1 = Fragments of Aquatic plants, Series $2=$ Fragments of Aquatic Animals, Series $3=$ Algae, Series $4=$ Diatoms, Series $5=$ Unidentified organisms, Series $6=$ Amorphous mass, Series $7=$ Sand Grains]

The GaSI and feeding intensity were reported higher in monsoon month in black tiger shrimps Penaeus monodo by Baskar et.al. (2013) and in present study similar variation in feeding was recorded in Macrobrachium assamense peninsulare. This variation in feeding is due to the plenty of preferable stuff in the microhabitat of these prawns in monsoon months as compared to other months. Variation in the FPI value was also observed monthly around the years in both seasonal and size-wise and it was due to the availability of food items in the stream 
(Sarkhanizadeh et al. 2014) showed seasonal variation in feeding according to season and correlated with nature of breeding. The higher FPI value of fragments of animal parts shows the omnivorous nature of animals. No significant pattern of FPI was observed in male and female individuals as both showed a similar food preference in quality-wise. From this feeding indices study, it is concluded that freshwater prawn $M$. assamense peninsulare mostly preferred animal material have little choice for plant matter. Our study gets support from the observation of some authors in $M$. acanthuru (Albertoni et al 2003); in M. lamarrei (Sharma and Subba, 2005), M. vollenhovenii (Jimoh et al 2011) and M. carcinu (Lima et al. 2014) was aired proved the omnivorous nature of some minor prawn species respectively.

Consequently, this study provides us basic information about the food and feeding rate of $M$. assamense peninsulare, which is an important aspect of the general biology study of this species that helps to understand the feeding biology and ecology of the streams. This study also helps to understand the food diversity and food preference of the animal which is an icon for aquaculture practices of this species for future, if required.

\section{Acknowledgments}

All authors gratefully acknowledge the UGC, New Delhi for providing National Fellowship for Higher Education (NFHE) first author to meet the contingent expenditure

\section{References}

Albertoni EF, Pama-Silva C, Esteves FA (2003) Overlap of dietary niches and electivity of three shrimp species (Crustacea, Decapoda) in tropical coastal lagoon (Rio de Janeiro, Brazil). Revista Bra. Zoo. 2091:135-140.

APHA (2012) Standard method for the examination of water and wastewater. APHA, AWWA, WPEC, $22^{\text {th }}$ Edition, New York.

Baskar S, Narasimhan N, Swamidass Daniel G, Ravichelvan R, Sukumaran M Anandaraj T
(2013) Food and Feeding Habits of Penaeus monodon (Fabricius) from Mallipattinam Coast in Thanjavur Dist, Tamil Nadu, India . Int. J. Res. Biol. Sci. 3(1): 1-4

Devi PL, Nair DG, Joseph A (2013) Habitat ecology and food and feed of the herring bow crab, Varun littereta (Fabricius 1798) of Cochi backwaters Kerala India. Arthop. 2(4): 172-188.

Euzen O (1987) Food habits and diet composition of some fishes of Kuwait. Kuwait Bull. Sci, 9: $65-86$

Froster JRM (1976) Studies on the development of compounded diets for prawn. Int. conference on aquaculture nutrition. Delaware sea program and U.S/Japan aquaculture panel. UJNR Pp: 229-248.

Jayachandra, KV and Joseph NY (1989) Food and feeding habits of the slender river prawn,

Macrobrachium idella (Hilgendorf, 1898) (Decapoda, Palaemonidae). Mahasagar; 22: 121-129.

Jimoh AA, Clarke EO, Whenu OO, Adeoye HB. 2011. Food and feeding habits of the African river prawn (Macrobrachium vollenhovenii, Herklots, 1857) in Epe Lagoon, southwest Nigeria. Int. J. Fis. Aquacul. 3(1):10-15.

Koshal Kumar, Kotnala, CB and Anita Rawat Rana (2016) Quantitative and Qualitative Gut Content Analysis Of Macrobrachium assamense peninsulare From Rawasan Stream of Garhwal Himalaya, Uttarakhand, India. Int. J. Adv. Res. 4 (12): 786-791.

Lima JDF, Garcia, JDS, Silva, TCD (2014) Natural diet and feeding habits of a freshwater prawn (Macrobrachium carcinus: Crustacea, Decapoda) in the estuary of the Amazon River. Acta. Amazo. 44(2):235-244

Marte CL. 1980. The food and feeding habit of Penaeus monodon Fabricius collected from Makato river, Aklan, Philippines (Decapoda: Natantia). Crust 38(3): 225-236.

Murthy DK and Rajagopal KV. 1990. Food and feeding habits of the freshwater prawn Macrobrachium equidens (Dana). Indian J. Anim. Sci. 60 (1): 118-122. 
Needham PR and Needham JG. 1962. A guide to the study of freshwater biology $5^{\text {th }}$ (ed.) Holden Day Incorporation.

Reddy SR and Shakuntala K. 1986. Use of my side as a food for culture of juvenile Peneaus merguienisis In: Biology of benthic marine organisms (Ed..F. Thomson R Sarojanni and R. Nagabhushanam) Oxford IBH, New Delhi Pp: 359-363.

Sarkhanizadeh A, Valinassab T and Fatemi MR. 2014. Evaluation of some feeding indices of Atrobucca nibe in the Northern Oman Sea. J. Nov. Appl. Sci. 3 (11): 1268-1274.

Sharma A and Subba BR (2005) General biology of freshwater prawn, Macrobrachium lamarrei (H. Milne-Edwards) of Biratnagar, Nepal. Our Nat. 3(1):31-41.

Ward HB and Whipple GC. 1959. Fresh Water Biology $2^{\text {nd }}(e d n$.) John Wily and Sons New York, London, Sydney Pp: 1243.

Williams MJ. 1981. Method for analysis of natural diet in portunid carbs (crustacea: Decapoda: portunidae). J. Exp. Mar. Biol. Ecol. 52: 103-113. 